\title{
EPISTEMIC MODALITY IN TED TALKS ON EDUCATION
}

\author{
Ton Nu My Nhat*, Nguyen Thi Dieu Minh \\ Department of Foreign Languages, Quy Nhon University \\ 170 An Duong Vuong, Quy Nhon, Binh Dinh, Vietnam \\ Received 7 December 2019 \\ Revised 20 May 2019; Accepted 26 July 2019
}

\begin{abstract}
This paper aims to investigate the epistemic markers in TED talks. The data for the study is 100 TED talks on education. The mixed method of both the quantitative and qualitative approaches was manipulated to capture the use of the linguistic means to convey epistemic modality in terms of degrees of certainty and range of devices. The findings indicate that epistemic modality is pervasive in this genre, with approximately one-tenth of the sentences in the data being epistemically modalized by TED speakers via a range of linguistic means of different types and epistemic strength. The analysis unveils a clear tendency to select the middle level of commitment and make use of epistemic modal auxiliaries to frame their statements with personal attitudes and opinions. The examination of epistemic devices in the data also suggests speakers' preference to use epistemic adverbials to realize certainty and employ epistemic modals to denote probability and possibility. The study yields pedagogical implications for developing an efficient use of epistemic modality in oral presentation of academic discourse.
\end{abstract}

Keywords: TED talks, epistemic modality, modality

\section{Introduction}

In today's modern society, along with technological advances, there is a plethora of easily accessible English language learning materials for education practitioners as well as those striving to learn English. Utilizing numerous media-based resources to accompany formal instructions has become an emerging trend in English language teaching and learning. Among a proliferation of resources available for educational purposes, the TED community represents one form of online information sharing that can be used as both main and supplementary accompaniment to English courses (Abdulrahman, 2017; Banker and Gournelos, 2013; Coxhead and Walls, 2012; Nicolle, Britton, Janakiram, and Robichaud, 2014). TED Talks (TTs) is a series

* Corresponding author. Tel.: 84-905242270

Email: tnmynhat70@gmail.com released free online. This site is a repository of audio-video recordings of talks delivered at global TED events where the world's most inspiring thinkers, leaders, and teachers talk passionately about the areas of expertise. The speeches are pithy and thought-provoking, with the prime goal of distributing "ideas worth spreading".

Multiple studies have been triggered by the various TED-based pedagogically potential impacts. TED has been recognized as useful for improving learners' listeningcomprehension skills. The recordings were implemented to elevate listening competences for students in undergraduate interpreting classes (Sung, 2014), and for English-learning students at college level (Abdulrahman, 2017). Authenticity is an essential characteristic of TTs that helps advance learners' listening skills. TED content is delivered by both native and non-native speakers with various accents, 
which is exactly what English learners are likely to encounter in real-life situations (Bianchi and Marenzi, 2016; Kedrowicz and Taylor, 2016). Regarding speaking competences, TED's thought-provoking speeches involve diverse voices, questions, and conflicting perspectives, which can ignite reflection, discussion, conversations, and critical thinking among learners (Nicolle et al., 2014). Abdulrahman's research (2017) discloses that most students were motivated to enter in-class activities based on TTs. The students in that study stated that the immersion in TED videos exposed them to different accents and helped them become accustomed to English sounds and the way they are used in real life, thus improving their pronunciation and intonation. Presentation skills, which are perceived as one of the most common spoken genres for learners in academic and workplace settings, as well as an integral factor leading to one's academic and professional success (Evans, 2013; Kim, 2006), also benefit from the use of TED videos (Chang and Huang, 2015; Kedrowicz and Taylor, 2016; Wang, 2012). As a professional presentation genre, TTs demonstrate great potential for shaping students' perception of public presentations, serving as powerful exemplars of how to command attention, disseminate ideas, and persuade broad audience (Kedrowicz and Taylor, 2016). Furthermore, TED presentations can enlarge learners' lexical and grammatical knowledge. By presenting new words' pronunciation and usage in appropriate context, TTs are a solid basis for high proficiency learners with academic goals to build knowledge of words in the mid-frequency bands; they help concepts that are difficult to explain verbally become easier to comprehend (Abdulrahman, 2017; Coxhead and Walls, 2012). In terms of English grammar, listeners could also be encouraged to learn about the grammar as they analyze the grammatical structures in the talks and the way they are utilized by speakers (Abdulrahman, 2017).

This study extends these pedagogicallymotivated research on TED. In this investigation, the syntactic features of TTs are captured in light of epistemic modality (henceforth EM) and we narrow the focus into one theme - education. Specifically, the questions this research is aimed to answer are:

(1) To what extent is EM utilized in TED Talks on education (TTsE)?

(2) How is EM realized in terms of the syntactic devices and degrees of certainty?

This article is organized as follows. Section 2 provides an overview of EM and its subtypes. Section 3 describes the research methodology. Section 4 is to provide the answers to the research questions. The article closes with the implications and suggestions for further studies.

\section{Theoretical background}

\subsection{Modality and subtypes of modality}

Studies on modality tend to approach this category by contrasting it with factuality. It has been widely discussed that language is not merely used for conveying factual information about the truth of the proposition of an utterance but also expressing one's attitudes, opinions, ideas and ideologies about the events (Aidinlou and Mohammadpour, 2012). Modality has been defined in terms of 'attitude' and 'judgment' (Lyons, 1977; Quirk, Greenbaum, Leech and Svartvik, 1985; Simpson, 1993 among others), or of 'possibility', 'probability', 'necessity', 'volition', 'obligation' and 'permission', along with others such as 'doubt', 'wish', 'regret', 'desire', and 'usuality' (Downing and Locke, 
1992), to name just a few. Lyons (1977, p.452) refers to modality as the speaker's “opinion or attitude towards the proposition that the sentence expresses or the situation that the proposition describes". Quirk et al. (1985, p. 219) claim that "at its most general, modality may be defined as the manner in which the meaning of a clause is qualified so as to reflect the speaker's judgment of the likelihood of the proposition it expresses being true". Others view modality as a major exponent of the interpersonal function of language (Simpson, 1993; Suhadi, 2011; Martin \& White, 2005). They note that modality refers to a speaker/ writer's attitude toward or opinion about the truth of a proposition expressed by a sentence as well as the attitude toward the situation or event described by a sentence. From a systemic functional perspective, Halliday and Matthiessen (2004, p. 618) describe modality as "the intermediate ground between positive and negative polarity" that construes "the area of meaning that lies between yes and no".

Scholars' different ways to delineate modality result in the fact that so far there is no consensus on its classifications, although "the number of modalities one decides upon is to some extent a matter of different ways of slicing the same cake" (Perkins, 1983, p. 10). Lyons (1977) makes a binary distinction between epistemic and deontic root. The former is concerned with matters of knowledge, belief, inference, or opinion; the latter relates to the necessity or possibility of acts performed by morally responsible agents, associating to such notions as moral obligation, permission and right conduct, which heavily depend upon societal and cultural norms, or on one's ethical criteria. There also exists a tripartite division between epistemic, deontic and dynamic, the third of which revolves around the capacities, potentials or needs of the (in)animate subject of the clause, either fully inherent to it or conditioned by external factors (von Wright, 1951). Still, other sub-types are mentioned in Palmer's (2001) work such as future, negative, interrogative, imperative-jussive, presupposed, conditional, purposive and resultative, wishes (desiderative) and fears (timitive), and, less commonly, habitualpast. In his systemic-functional framework, Halliday (1994) puts forward another approach towards modality as he distinguishes between modalization and modulation. Modalization is the speaker's judgment to propositions, in which the meaning of the positive and negative pole is asserting ("it is so") and denying ("it isn't so"). On the other hand, modulation is concerned with the meaning of proposals in the positive and negative poles in prescribing ("do it") and proscribing ("don't do it").

On the whole, there has been a proliferation of terminology to distinguish different kinds of modality. For the purposes of this study, we follow the perspective of the researchers who draw the basic distinction between the category of epistemic and non-epistemic modality, the latter of which comprises deontic and dynamic modality. The next subsection will further deal with only EM, which is the focus of this paper.

\subsection{Epistemic modality and subtypes of epistemic modality}

The term 'epistemic' derives from 'episteme', the Greek word for 'knowledge'. Most authors (eg. Hoye, 1997; Lyons, 1977; Martin, 2001) hold that EM is related to 'belief' and 'knowledge'. Others involve 'truth' in their definitions. Coates (1983) sees EM as being concerned with the speaker's assumptions or assessment of possibilities, and in most cases, indicating his reservations about asserting the truth of the proposition. Similarly, Huddleston (1984) argues that 
"epistemic modality is concerned with the truth status of the proposition in the light of what the speaker knows. Epistemic modality is orientated towards the speaker - it is subjective”. El-Hassan (1990) shares the same perception in the subjectivity of the notion, explaining that "epistemic modals do not express objective, known reality, but the inferential judgment of the speaker as informed by circumstantial evidence and/or experience”. For Palmer (1986), 'epistemic' should apply to any modal system that indicates the speaker's (lack of) commitment to the truth of the proposition expressed as well as the degree of commitment by the speaker to what he says. Bybee, Perkins and Pagliuca (1994) describe epistemic as a domain whose markers indicate something less than a total commitment by the speaker to the truth of the proposition, whereas the unmarked case is total commitment to the truth of the proposition.

Various distinctions have been made in the literature with regard to the subtypes of EM, such as subjective and objective (Lyons, 1977); subjective, intersubjective, and neutral (Nuyts, 2000). EM is also divided into subcategories based on degrees of certainty. It has long been acknowledged that the strength of the speaker's commitment to his assertion and the degrees of certainty are gradable corresponding to the high or low degree of likelihood/probability or the speaker's certainty.

Table 1: EM Lexical items according to degrees of commitment and word class

\begin{tabular}{|c|c|c|}
\hline Certainty & Probability & Possibility \\
\hline \multicolumn{3}{|c|}{ Verbs/ Verbal expressions } \\
\hline $\begin{array}{c}\text { bet, can only think, can't think, } \\
\text { come to a/the conclusion, } \\
\text { couldn't believe, } \\
\text { not doubt, } \\
\text { have no doubt, } \\
\text { have no reason to believe, } \\
\text { know, emphatically say, } \\
\text { see no reason to doubt, } \\
\text { take it }\end{array}$ & $\begin{array}{l}\text { appear, assume, believe, estimate, } \\
\text { expect, feel, find, gather, guess, } \\
\text { hope, imagine, look, occur to me, } \\
\text { recall, regard, seem, sound, suggest, } \\
\text { suppose, take the view, think, } \\
\text { understand } \\
\text { if I remember }\end{array}$ & $\begin{array}{c}\text { doubt, wonder, } \\
\text { I cannot rule out the } \\
\text { prospects }\end{array}$ \\
\hline \multicolumn{3}{|c|}{ Adverbs/ Prepositional phrases } \\
\hline $\begin{array}{l}\text { certainly, clearly, definitely, } \\
\text { evidently, for all I know, } \\
\text { for all I've been told, } \\
\text { in all probability, } \\
\text { in truth, indeed, (in) no doubt, } \\
\text { obviously, of course, plainly, } \\
\text { surely, without question }\end{array}$ & $\begin{array}{l}\text { apparently, as far as I can see, } \\
\text { as far as I know, } \\
\text { as far as I remember, } \\
\text { as I understand it, } \\
\text { from what I (can) understand, } \\
\text { in my mind, } \\
\text { in my view, } \\
\text { quite likely, most likely, (not) likely, } \\
\text { presumably, probably, seemingly, } \\
\text { so far as appeared, } \\
\text { supposedly, to judge from, to my } \\
\text { mind, probably }\end{array}$ & $\begin{array}{l}\text { maybe, } \\
\text { perhaps, } \\
\text { possibly, } \\
\text { conceivably }\end{array}$ \\
\hline \multicolumn{3}{|c|}{ Adjectives } \\
\hline
\end{tabular}




\begin{tabular}{|c|c|c|}
\hline $\begin{array}{c}\text { certain, clear, confident, } \\
\text { convinced, evident, highly } \\
\text { unlikely, incredible, obvious, } \\
\text { positive, sure, true }\end{array}$ & alleged, apparent, likely, suggested & uncertain, unsure \\
\hline \multicolumn{2}{|c|}{ Nouns/Nominal expressions } \\
\hline $\begin{array}{c}\text { all I know, } \\
\text { it's common ground, } \\
\text { (that) conclusion, (the) claim, } \\
\text { there is a considerable } \\
\text { possibility, there is no doubt/ } \\
\text { suggestion/ question }\end{array}$ & estimate, guess, guesswork, thought & possibility \\
\hline
\end{tabular}

In this regard, EM is concerned with users' degree of certainty or commitment to the truth of their statements. Leech and Svartvik (1975) speak of "scale of likelihood", stating that a proposition cannot be considered in black-and-white terms, but in terms of a scale of likelihood, the extremes of which are impossibility and certainty (or logical necessity). While there is an on-going discussion on whether EM markers should be arranged on a continuum or in discrete categories, there seems to be an agreement that there exist at least three articulated points in the gradual epistemic continuum - high, median and low (Carretero, 2002; Halliday, 1994); and speculative, deductive, and assumptive (Palmer, 2001). Among a host of different terms, the most commonly expressed epistemic grades are possibility, probability, and (inferred) certainty (Bybee et al., 1994; Kärkkäinen, 2003; Holmes, 1982; Hyland and Milton, 1997; Suhadi, 2011 among others). Epistemic possibility conveys the lowest degree of confidence based on the speaker's knowledge on the proposition; Epistemic probability conveys the median degree of confidence based on the speaker's knowledge of the proposition; and Epistemic certainty conveys the highest degree of confidence based on the speaker's knowledge of the proposition. The taxonomy adopted in this study is the widely-used epistemic trichotomy of certainty, probability, and possibility.

Regarding the linguistic clues, or technically 'epistemic markers', the pervasiveness of modal auxiliaries has always been emphasized (Aidinlou and Mohammadpour, 2012; Gustová, 2011; Kranich, 2009, among others). Lyons (1977) was among the first to include different epistemic modality markers (EMMs) that were not based on modal verbs alone, claiming that various devices such as lexical verbs, nouns, adjectives, adverbs, and multi-word units are available to refer to how certain the speaker feels about the content of his/her utterance. An in-depth overview of epistemic modals is offered by Gustová (2011), who mingles the perspective of Leech and Svartvik (1975) and Quirk et al. (1985) and lists 'can', 'could', 'may', 'might', 'must', 'should', 'ought to', 'will', 'would', and 'shall' as modals expressing EM. Unlike modal auxiliaries, other types of epistemic realizations have received a disproportionate amount of attention from linguists. Dirven (1989) notes that there exists a long tradition to solely or predominantly concentrate on the modal auxiliaries and exclude other expressions. However, having studied modality in large amounts of discourse, Hermerén (1978) and Holmes (1983) show a wide range of lexical items carrying modal meanings. The analyses 
show that, put together, other word classes express modality more frequently than modal verbs, and that verbs and adverbs appear considerably more frequently than nouns and adjectives. On the whole, it is likely that different researchers have their own mindsets when determining the level of commitment that each epistemic marker denotes. Drawing heavily on the results of the previous studies on this domain (Biber et al., 1999; Caliendo and Compagnone, 2014; Carretero, 2002; Chafe, 1986; Gustová, 2011; Hoye, 1997; Hyland, 1998; Kärkkäinen, 2003; Leech and Svartvik, 1975; and Quirk et al., 1985), we categorize the lexical items denoting EM in terms of levels of commitment and of word class, presented in Table 1.

\section{Research methodology}

\subsection{Data description}

TTs revolve around a host of highinterest professional and academic topics, including technology, business, science, education, politics, pollution, healthcare, etc. At the moment, available on the site are over 2600 high-quality videos, most of which are accompanied by time-stamped transcripts. The data for this preliminary study is 100 TTs randomly downloaded from over 250 talks on education accessible from the moment of data collection. Three criteria were observed. First, the speeches selected are of less than 16 minutes, which are in the vast majority in the series. Second, the talks must be delivered first hand in English rather than translated from another language. Third, the talks are presented by one speaker.

\subsection{Data analysis}

To address the research questions put forward, the mixed method of both the quantitative and qualitative approaches was manipulated. To analyze the EMMs, first of all notes of laughs and applause, special characters and time codes were removed from the scripts. Then, each talk was divided, counted, and analyzed in terms of sentences. In this study, by 'sentence', we mean the traditional structure beginning with a capitalized letter and ending with a full stop, a question mark or an exclamation mark. After a manual analysis was carried out to identify and categorize the EMMs, the statistical analysis was conducted to arrive at the percentage of the epistemically modalized sentences as well as the frequencies of the EMMs in terms the syntactic devices and degrees of certainty.

It should also be noted that although we closely followed the classification summarized in Table 1, in some cases, the devices were categorically supported or rejected by the context of use. For instance, the devices in (1) and (2) are supposed to be marked as probability, but due to 'great', and 'strongly', they were counted as EM of certainty. In the same manner, the markers in (3) and (4), which are usually considered as realizations of certainty, were listed in the group of probability because of the collocation with 'pretty'.

(1) But I have great hope that we're on our way to curing this disease. (B. Nowinski)

(2) I strongly believe that when we do all of these things, we find that the rising Africa narrative is not a fluke. (N. Okonjo-Iweala)

(3) Men don't belong here, that's pretty obvious. (A. Carr-Chellman)

(4) Well, we parents, we parents are pretty sure it's all worth it. (J. Lythcott-Haims)

\section{Findings and discussion}

\subsection{Findings}

The analysis of the $100 \mathrm{TTsE}$ revealed that nearly 10 percent $(9.62 \%)$ of the sentences 
are epistemically modalized by markers of various types and epistemic strength. It is noticeable that EM is consistently employed in every single presentation of the data. The speakers may employ only one marker or up to four markers in each sentence. For instance,

(5) Now, this is a moment where you probably feel very guilty about what you just did. (S. DeWitt)

(6) I think you all must be aware of it, but I'll still list it for the few who don't. (A. Gupta)

(7) So they might bring in money, they might bring in people, they might bring in technology. (S. Bansal)

(8) I think there are a lot of reasons, but I first want to address the one that you're probably most likely to have heard of, because actually it's more dangerous than you might think. (J. McWhorter).

The data concerning the levels of commitment is summarized in Figure 1. The analysis unfolded a clear preference for selecting the shade of probability, making up over half $(51 \%)$ of all the cases counted. For example,

(9) There is the quickest way advances are likely to occur, as measured in discoveries per investigator per year. (E.O. Wilson)

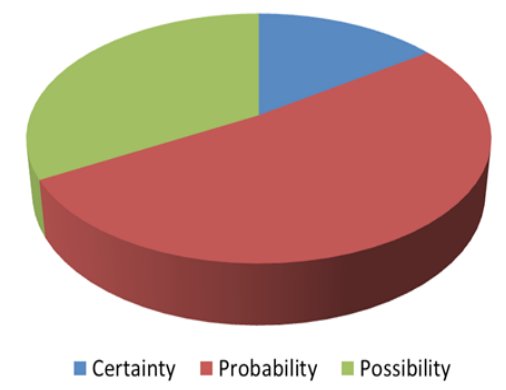

Figure 1: Occurrence frequency of three levels of commitment
(10) This is probably the biggest problem facing our society. (S. Reshef)

Contrary to the predominance of probability, possibility and certainty appear far less frequent. However, even though the speakers committed to both stronger and weaker claims, it is apparent that they tend to choose more devices of possibility than those of certainty, with the former approximately doubling the latter (33.12\% vs. $15.27 \%)$. We have examples of possibility such as (11) and (12), and of certainty such as (13) and (14).

(11)Perhaps as a gun owner, you should also ask whether you have been taking care of your mental health? (D. Wolk-Rogers)

(12)It can also be motivating, and it provides us with information to identify what to focus on next when we go back to the learning zone. (E. Briceño)

(13) And as jobs continue to leave my community, and energy continues to come in, be exported in, it's no wonder that really some people refer to the South Bronx as a desert. (S. Ritz)

(14)So if it can find a word which is a planet and which is co-occurring with these keywords, that must be the answer. (N. Arai)

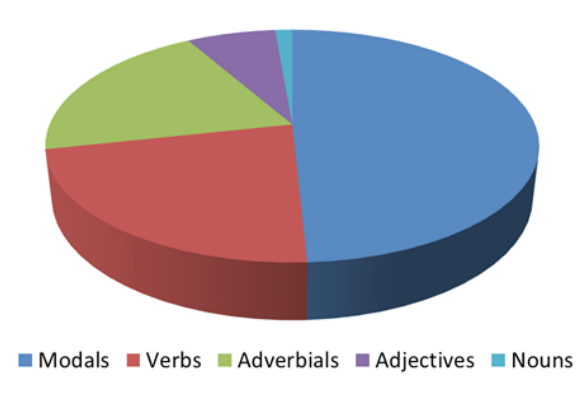

Figure 2: Occurrence frequency of five categories of markers 
Figure 2 presents the proportions of the different types of EMMs used in the data. The most noticeable feature is that modals significantly outnumber the other types of devices, accounting for nearly a half (49.20\%). This finding is in line with the others reported by Aidinlou and Mohammadpour (2012), Gustová (2011), Kranich (2009) and Šolienė (2013) that modals are the most frequent makers of EM.

The overall results show that to tone down their statements, the presenters also made great use of lexical verbs and adverbs and prepositional phrases, $22.41 \%$ and $20.09 \%$ respectively. It is apparent that epistemic adjectives and nouns are the least frequent types of markers in the data, accounting for only $6.96 \%$ and $1.34 \%$ apiece. That EM in spoken English is seldom expressed by adjectives and nouns is in consonance with the findings of Letica (2009) and Recsky (2006). Examples of each category are as follows.

(15)It might surprise you to learn that we've actually thought about this before. (D. Wolk-Rogers)

(16)I presume he has a worldview. (J. McWhorter)

(17)And, of course, the brain of the robot is working in the remote server. (N. Arai)

(18)I am convinced that Africa's further transformation, Africa's advancement, rests simply in the acknowledgment, validation and mainstreaming of Africa's own traditional, authentic, original, indigenous knowledge in education, in research, in policy making and across sectors. (C. Ezeanya-Esiobu)

(19)There was no question that his children would receive an education, including his daughters, despite the Taliban, despite the risks. (S. Basij-Rasikh)

Specifically, as regards the modals, there is a significant superiority of modals denoting probability, which are 'will' and 'would' as well as their negative forms. 'Will', being the most frequent epistemic modals in the data, makes up $23.05 \%$ of the total, whereas 'would' accounts for a marginally lower percentage of $21.42 \%$. The next four positions in the list are taken up by 'might', 'can', 'could' and 'may', which constitute $17.79 \%, 12.52 \%, 11.25 \%$ and $9.25 \%$ respectively. Accounting for less than $5 \%$, 'should', 'must', and 'ought to' are the least favorite modals in the investigated TTsE. Then, of the epistemic lexical verbs, 'think' is the most frequent, at up to $39.44 \%$; the others are 'seem', 'believe', 'know', 'sound', 'feel', 'hope', 'guess', 'say', 'argue', 'seem like', 'sound like', 'feel like', 'bet', 'fear', 'find', 'look', 'predict', 'estimate', 'figure', 'look like', 'presume', 'wonder'. As far as epistemic adverbials are concerned, 'maybe' is of the highest use (25.33\%). Ranking in the second place is 'of course' (24\%). 'Probably' and 'perhaps' come next (18.67\% and 10.67\% respectively), 'certainly' accounting for $4 \%$. All the others are found to take up less than $18 \%$. The results obtained are partially in line with claims made by Biber et al. (1999) and Kärkkäinen (2003), who listed 'maybe', 'probably', 'of course', 'perhaps', 'certainly', and 'definitely' as six most prevailing epistemic adverbs. Ranked in the fourth place are the epistemic adjectives. Of this word class, it is note-worthy that speakers made extensive use of 'likely' to express their hesitation to commit to the utterances, which makes up precisely $50 \%$ in total. Meanwhile, 'possible/ impossible' and 'sure', the next two most frequent adjectives, account for only $17.95 \%$ and $14.10 \%$. Five other adjectives (obvious, convinced, clear, doubtful, true) take up less than $10 \%$ each. Nouns are the least favorite word form to be used as epistemic devices as only 15 cases were found throughout 100 talks under investigation. Mention should be made 
of the fact that 'chance', 'odds' and 'wonder' were equally used in three cases, taking up exactly $20 \%$ each. 'Hope' ranks second with $13.32 \%$, while 'conclusion', 'probability', 'question' and 'potential' appeared only once each in the whole data.

The findings also highlight insightful findings on the relationship between types of EMMs and degrees of certainty they denote. The results unfold that certainty is realized chiefly by epistemic adverbials. This cooccurrence accounts for as high as $44 \%$, while the combination between certainty and epistemic adjectives ranks second with slightly over $19 \%$. By contrast, epistemic modals are found to be the main realization of probability and possibility, constituting around $44 \%$ and $73 \%$ in frequency respectively.

\subsection{Discussion}

A notable feature that contributes to TED's success is its highly polished and succinct onstage presentation. Coxhead and Walls (2012) state that TED presentations are often carefully scripted and closer to written texts than spoken texts when compared to conference papers and movie scripts. From the results of this study of TTs with a focus on EM, we argue that the skillful use of this means of expression must play a role in attributing high effectiveness to this highprofile genre.

Regarding the distribution of EM, it is most noteworthy that EM is present in every speech and nearly $10 \%$ of the sentences of the whole data are modalised with EM. This tendency evidences that this semantic domain constitutes a frequent phenomenon in this genre of academic orality. The pervasiveness of EM realizations in TED evidences statements of Martín (2001), who claims that EM constitutes a crucial rhetorical device in academic discourse since it allows authors to mitigate the degree of commitment to the truth of a proposition, thus reducing the risk of opposition and minimizing the facethreatening acts to the general audience.

Nevertheless, close analysis reveals an unequal distribution of EM among the talks: some presenters used up to nearly 40 epistemic devices in their talks; others employed only one marker during the whole presentations. This disproportionate frequency can be mainly attributed to the varied time spans, speakers' styles, and talks' contents. As for the length of time, the duration of talks constituting the data, which ranges from 2 minutes to 16 minutes, might vastly influence the number of EMMs used. Within a short amount of time, speakers are liable to be more straightforward when presenting the findings while in longer speeches, there may be some more room for scholars to set the premise of their arguments or to open up further discussions, resulting in the employment of more EMMs. Then, as regards the presenters' style, the fact that this study focuses on verbal means of EM only can affect the number of EMMs in each talk because this dimension of meaning is not solely realized by verbal but also non-verbal devices. Since TED platform offers a direct contact between the speakers and their audience, which the scripts are deprived of, several scholars may opt for gestures, stress or intonation as ways to interact with their interlocutors, thus reducing the number of epistemically modalized sentences found in certain talks. Finally, with a focus on education, the TTs under analysis serve two particular purposes - to present knowledge claims and to inspire listeners. In the speeches aimed primarily to publicly state new findings, EM seems to be more common as it enables researchers to justify the contribution and further implications of their works and to indicate possible gaps and limitations as well. The inspiring talks, by contrast, often convey 
the messages through the narration of speakers' past events and experiences, which leave not much space for the realizations of EM.

As far as the levels of commitment are concerned, the findings suggest a marked preference for the devices denoting probability over the degree of possibility and certainty. It is understandable that these TED presenters refrain from markers realizing certainty since they wish to avoid imposing newly established knowledge on the general audience. Besides, desisting from making assertive statements allows academics to create a research space in the field and to diminish the risk of facing potential criticism from the international community as well. That the degree of possibility is less dominant could be probably due to the fact that it entails a certain level of ambiguity, which is somewhat inappropriate in public presentations and may also negatively influence the speakers' image as an expert or professional on stage. Given that scholars cannot overuse certainty and possibility, it is no wonder that those who expect to gain worldwide recognition for their works would prefer probability to mitigate claims in their talks. In the formal context of public talks, probability, which expresses the intermediate point in the epistemic continuum, enables specialists to inform the audience of their research while still expressing their concern for an appropriate level of factuality in their statements.

Regarding the distribution of EM linguistic exponents, epistemic modals significantly outnumber the other types of devices. The strong preference for epistemic modals can be attributed to its mobility and simplicity. As for the mobility feature, epistemic modals can be inserted in any assertive proposition to alleviate its truth-value. They could be combined with personal pronouns, noun phrases, nominal clauses, and the impersonal "it" or the existential "there" to form a sentence. The frequent use of adverbs and prepositional phrases is also in accordance with the previous research which affirms that these syntactic structures, due to their great mobility which allows the speaker to insert them whenever during the proposition, are the most frequent markers of epistemic stance in spoken English (Biber et al., 1999; Kärkkäinen, 2003). Meanwhile, epistemic adjectives and nouns are found to be the least frequent types. However, it is the use of these devices, which tend to occur in fixed constructions, that lends grammatical range and accordingly attraction and persuasion to the talks. A list of these fixed constructions is provided in Appendix B. The appearance of a wide range of EMMs in this relatively formal context allows specialists to "diminish their discoursal argumentative degree of disagreement with the ideas sustained by other authors" (Martín, 2001, p.203) and orient lay interlocutors regarding how to interpret the factuality of their personal findings (Ciapuscio, 2007).

\section{Conclusions, implications, and suggestions for further studies}

\subsection{Conclusions}

The study is an in-depth enquiry into EM in TTsE. The statistic figures prove that it is an extremely frequent phenomenon in TTsE, consolidating its position as one of the central rhetorical devices contributing to the success of this genre. EM is often utilized in the context of academic discourse where authors, who have awareness of the imposition their new knowledge may present, search for " $a$ linguistic measure of precaution" so as to soften the contrast between their research findings and prior existent knowledge (Graefen, 2007). Regarding the degree of commitment preferred the most by TED 
presenters, a keen interest in the category of devices denoting probability was noticed. The high frequency of probability seems to be reasonable as assertive statements may pose a risk of facing potential criticism from the international community for academics, while the ambiguity of possibility can also damage speakers' image as an expert or professional on stage. Besides, the examination of the data unveils an imbalance in the use of different types of EMMs. The statistically significant preference for epistemic modal auxiliaries, which can be attributed to its mobility and simplicity, considerably outnumbers that of epistemic lexical verbs, adverbs and prepositional phrases. Epistemic adjectives and nouns prove to be the least frequent types of markers in the data.

\subsection{Pedagogical implications}

It has long been established that EM is of central importance to the formation of argument in both spoken and written discourse and that the ability to express doubt and certainty in academic discourse is vital to successful academic communication. Nevertheless, most research has pointed out that second/foreign language learners have a high likelihood of encountering problems when it comes to expressing more subtle differences in various levels of assertion. Nonnative writers differ significantly from native writers in relying on a more restricted range of epistemic expressions than native speakers, offering stronger commitments, and exhibiting greater problems in conveying a precise degree of certainty (Coates, 1987; Kärkkäinen, 1992; Letica, 2009; Hyland and Milton, 1997; Martín, 2001). English learners' difficulties in interpreting and employing EM are attributed not only to the various realizations and crosslinguistic and cross-cultural interference, but also to the lack of instruction and practice in traditional classrooms as well as limited explanation of the correct use of this domain in the academic materials (Flowerdew, 2001; Hyland and Milton, 1997).

Therefore, it is hoped the overall picture of the efficient use of EM in TTsE in terms of different levels of commitment and range of linguistic devices drawn from this study would be insightful to the teachers and learners of EFL. The investigation contributes to increasing our greater awareness of why, what, and how to make the best use of EM in developing public speaking skill in general and oral presentations of academic discourse in particular. The expressions denoting the degrees of certainty listed in Table 1 and Appendix B might serve as a source of reference for learners of various proficiency levels to learn how to precisely express their judgments and personal attitudes toward the factuality of the propositions in everyday communication and public presentations. Comprehending the use of EM as well as the levels of commitment it denotes also helps students properly interpret the exact meaning each proposition conveys.

\subsection{Suggestions for further research}

The findings obtained from this study provide a foundation for some further inquiries. Although the research has reached its aims, there remain some unavoidable limitations which need to be acknowledged and addressed in future research. Firstly, no differentiation was made in the data collection and data analysis between the talks delivered by the English native speakers and non-native speakers. This decision prevented us from reaching any conclusions about the use of EM across the two groups. As a result, it is advisable for this examination to be included in later studies on this domain. Secondly, since this research concentrated on talks on 
only education, it would be instructive to explore the use of EM in those that cover other disciplines. Then, it is widely acknowledged that in spoken language EM can be realized by not only the lexical devices; non-lexical devices such as prosodic or paralinguistic components are also profusely made use of (Coates, 1987; Gabrielatos and McEnery, 2005; Letica, 2009). Therefore, in-depth analyses in the future could be conducted to examine other epistemic means. Finally, this study was confined to the data in English and heavily withdrawn from literature on modality in English. An additional study of the Vietnamese translations of these talks based on the taxonomies proposed by the Vietnamese authors (Đỗ Hữu Châu, 1998; Lê Đong and Nguyễn Văn Hiep, 2001; Cao Xuân Hạo, 1991; Nguyễn Văn Hiệp, 2008) would certainly yield an insightful picture of EMMs in TTsE from a cross-linguistic perspective.

\section{References}

\section{Vietnamese}

Đỗ Hữu Châu (1998). Co sở ngũ nghĩa học tù vựng. Hà Nội: NXB Giáo dục.

Lê Đông, Nguyễn Văn Hiệp (2001). Ngũ nghĩa - ngũ dụng các tiểu tù̀ tình thái trong tiếng Việt. Công trình khoa học cấp Đại học Quốc gia. Đại học Quốc gia Hà Nội.

Cao Xuân Hạo (1991). Tiếng Việt - So thảo ngũ pháp chức năng, Quyển 1. TP. HCM: NXB Khoa học xã hội.

Nguyễn Văn Hiệp (2008). Co sở ngũ nghĩa phân tích cú pháp. Hà Nội: NXB Giáo dục.

\section{English}

Abdulrahman, T. (2017). TED Talks as Listening Teaching Strategy in EAP Classroom. The ASIAN EFL Journal, Tesol Indonesia International Conference Edition, Volume 10, 71-92.

Aidinlou, N. A., \& Mohammadpour, S. (2012). An Investigation of Epistemic Modality in Literary Texts. International J. Soc. Sci. \& Education, 2(4), 729-737.
Banker, C., \& Gournelos, T. (2013). TED Talks and the Need for a Changing Education System. Florida Communication Journal, 41(2), 39-56.

Bianchi, F., \& Marenzi, I. (2016). Investigating Student Choices in Performing Higher-order Comprehension Tasks Using TED Talks in LearnWeb. Lingue e Linguaggi, 19(2016), 23-40.

Biber, D., Johansson, S., Leech, G., Conrad, S., \& Finegan, E. (1999). Longman Grammar of Spoken and Written English. Harlow: Pearson Education Limited.

Bybee, J., Perkins, R., \& Pagliuca, W. (1994). The Evolution of Grammar: Tense, Aspect and Modality in the Languages of the World. Chicago/ London: University of Chicago Press.

Caliendo, G., \& Compagnone, A. (2014). Expressing Epistemic Stance in University Lectures and TED Talks: A Contrastive Corpus-based Analysis. Lingue e Linguaggi, 11(2014), 105-122.

Carretero, M. (2002). The Influence of Genre and Register on Epistemic Modality in Spoken English: A Preliminary Study. Estudios Ingleses de la Universidad Complutense, 10(2002), 11-41.

Chafe, W. (1986). Evidentiality in English Conversation and Academic Writing. In W. Chafe, \& J. Nichols (eds), Evidentiality: The Linguistic Coding of Epistemology (pp.261-272). Norwood, NJ: Ablex.

Chang, Y.-j., \& Huang, H.-T. (2015). Exploring TED Talks as a Pedagogical Resource for Oral Presentations: A Corpus-based Move Analysis. English Teaching \& Learning, 39(4), 29-62.

Ciapuscio, G. E. (2007). Epistemic Modality and Academic Orality - Pilot Study for COTECA (Corpus Textual del Español Científico de la Argentina). In G. Parodi (ed.), Working with Spanish corpora. London: Continuum.

Coates, J. (1983). The Semantics of the Modal Auxiliaries. London and Canberra: Croom Helm.

Coates, J. (1987). Epistemic Modality and Spoken Discourse. Transactions of the Philological Society, 85(1), 110-131. 
Coxhead, A.J., \& Walls, R. (2012). TED Talks, Vocabulary, and Listening for EAP. The TESOLANZ Journal, 20(2012), 55-65.

Dirven, R. (1989). Cognitive Linguistics and Pedagogic Grammar. In G. Leitner, \& G. Graustein (eds), Linguistic Theorizing and Grammar Writing (pp.56-75). Tübingen: Niemeyer.

Downing, A., \& Locke, P. (1992). A University Course in English Grammar. New York: Prentice Hall International.

El-Hassan, S. (1990). Modality in English and Standard Arabic: Paraphrase and Equivalence. Journal of King Saud University, 2(20), 149-166.

Evans, S. (2013). “Just wanna give you guys a bit of an update": Insider Perspectives on Business Presentations in Hong Kong. English for Specific Purposes, 32(4), 195-207.

Flowerdew, J. (2001). Academic Discourse. London: Longman, Pearson Education.

Graefen, G. (2007). Hedging. In S. Kranich (ed.), Epistemic Modality in English Popular Scientific Texts and Their German Translations. Trans-kom, 2(1), 26-41.

Gustová, I. (2011). The Ways of Expressing Epistemic (Extrinsic) Modality in Spoken English. Unpublished Undergraduate Thesis. University of West Bohemia.

Halliday, M. A. K. (1994). An Introduction to Functional Grammar (2 ${ }^{\text {nd }}$ ed.). London: Arnold.

Halliday, M. A. K. \& Matthiessen, C. M. I. M. (2004). An Introduction to Functional Grammar ( $3^{\text {rd }}$ ed.). Oxford: Oxford University Press.

Hermerén, L. (1978). On Modality in English. Lund: CWK Gleerup.

Holmes, J. (1982). Expressing Doubt and Certainty in English. RELC Journal, 13(2), 9-28.

Holmes, J. (1983). Speaking English with the Appropriate Degree of Conviction. In C. Brumfit (ed.) Learning and Teaching Languages for Communication: Applied LinguisticPperspectives. London: CILT.

Hoye, L. (1997). Adverbs and Modality in English. London: Longman.
Huddleston, R. (1984). Introduction to the Grammar of English. Cambridge: Cambridge University Press.

Hyland, K. (1998). Hedging in Scientific Research Articles. Amsterdam: John Benjamins.

Hyland, K., \& Milton, J. (1997). Qualification and Certainty in L1 and L2 Students' Writing. Journal of Second Language Writing, 6(2), 183-205.

Kärkkäinen, E. (1992). Modality as a Strategy in Interaction: Epistemic Modality in the Language of Native and Non-native Speakers of English. Pragmatics and Language Learning, 3, 197-216.

Kärkkäinen, E. (2003). Epistemic Stance in English Conversation. Philadelphia: John Benjamins.

Kedrowicz, A. A., \& Taylor, J. L. (2016). Shifting Rhetorical Norms and Electronic Eloquence: TED Talks as Formal Presentations. Journal of Business and Technical Communication, 30(3), 352-377.

Kim, S. (2006). Academic Oral Communication Needs of East Asian International Graduate Students in Non-science and Nonengineering Fields. English for Specific Purposes, 25(4), 479-489.

Kranich, S. (2009). Epistemic Modality in English Popular Scientific Texts and Their German Translations. Trans-kom, 2(1), 26-41.

Leech, G., \& Svartvik, J.(1975). A Communicative Grammar of English. Harlow: Longman.

Letica, S. (2009). Use of Epistemic Modality by Non-native Speakers of English. In R. Lugossy, J. Horváth, \& M. Nikolov (eds), UPRT 2008: Empirical Studies in English Applied Linguistics (pp.119-134).

Lyons, J. (1977). Semantics (Vol. 2). Cambridge: Cambridge University Press.

Martín, P. M. (2001). Epistemic Modality in English and Spanish Psychological Texts. Revista de Lenguas para Fines Especificos, 8, 197-208.

Martin, J. R. \& White, P. R. R. (2005). The Language of Evaluation. New York: Palgrave MacMillan. 
Nicolle, E., Britton, E., Janakiram, P., \& Robichaud, P.-M. (2014). Using TED Talks to Teach Social Determinants of Health. Canadian Family Physician, 60(9), 777-778.

Nuyts, J. (2000). Epistemic Modality, Language and Conceptualization. A cognitivepragmatic Perspective. Amsterdam/Philadelphia: John Benjamins.

Palmer, F. R. (1986). Mood and Modality. Cambridge: Cambridge University Press.

Palmer, F. R. (2001). Mood and Modality (2 ${ }^{\text {nd }}$ ed.). Cambridge: Cambridge University Press.

Perkins, M. R. (1983). Modal Expressions in English. London: Frances Pinter.

Quirk, R., Greenbaum, S., Leech, G., \& Svartvik, J. (1985). A Comprehensive Grammar of the English Language. Harlow: Longman.
Recsky, L. (2006). Epistemic Modality and Spoken Discourse: an English-Portuguese Crosslinguistic Investigation. Linguagem \& Ensino, 9(1), 159-185.

Simpson, P. (1993). Language, Ideology and Point of View. British Library Catalogue.

Suhadi, J. (2011). Epistemic and Deontic Modality: Two Sides of a Coin. JULISA, 11(2), 156-179.

Sung S.-e. (2014). Using TED in the Undergraduate Interpreting Classroom to Enhance Listening Competence. STEM Journal, 15(1), 219-236.

von Wright, G. H. (1951). An Essay in Modal Logic. Amsterdam: North- Holland Pub. Co.

Wang, Y.C. (2012). An Exploration of Vocabulary Knowledge in English Short Talks: A corpus-driven Approach. International Journal of English Linguistics, 2(4), 33-43.

\title{
TİNH THÁI NHẬN THỨC TRONG CÁC BÂI TED VỀ GIÁO DỤC
}

\author{
Tôn Nữ Mỹ Nhật, Nguyễn Thị Diệu Minh \\ Khoa Ngoại ngũ, Trưòng Đại hoc Quy Nhon \\ 170 An Dưong Vưong, Quy Nhơn, Bình Định, Việt Nam
}

Tóm tắt: Bài viết này nghiên cứu các phương tiện biểu đạt ý nghĩa tình thái nhận thức trong các bài TED. Công trình dựa trên dữ liệu bao gồm 100 bài TED về lĩnh vực giáo dục. Chúng tôi kết hợp cả hai phương pháp phân tích định tính và định lượng để xác định, miêu tả, và lý giải hệ thống các phương tiện biểu đạt ý nghĩa tình thái nhận thức được sử dụng. Chúng tôi tập trung vào hai khía cạnh mức độ cam kết của người nói và các phương tiện ngôn ngữ. Kết quả khảo sát cho thấy nét nghĩa này xuất hiện phổ biến trong thể loại này. Về mức độ cam kết, các diễn giả có xu hướng lựa chọn mức độ trung bình vượt trội so với mức độ ít chắc chắn hơn và chắc chắn hơn. Về các phương tiện ngôn ngữ, kết quả nghiên cứu cho thấy một bức tranh phong phú về phương tiện được sử dụng, với động từ tình thái có tần số sử dụng lớn nhất, tiếp theo sau là động từ và trạng từ; tính từ và danh từ xuất hiện trong các cấu trúc cố định cũng được sử dụng. Những kết quả của công trình nghiên cứu này đóng góp vào thực tiễn dạy học tiếng Anh về các phương tiện ngôn ngũ biểu đạt ý nghĩa tình thái nhận thức nhằm phát triển kỹ năng hùng biện bằng tiếng Anh như một ngoại ngữ nói chung và trình bày các nội dung học thuật nói riêng.

Tù khóa: Bài TED, tình thái nhận thức, tình thái 


\section{Appendix A. Data sources: List of 100 TTsE}

\begin{tabular}{|c|c|c|}
\hline Talk & Title & Speaker \\
\hline & 3 fears about screen time for kids - and why they're not true & S. DeWitt \\
\hline & 3 rules to spark learning & R. Musallam \\
\hline & 4 pillars of college success in science & F. Hrabowski \\
\hline & 4 reasons to learn a new language & J. McWhorter \\
\hline & A 12-year-old app developer & T. Suarez \\
\hline & A delightful way to teach kids about computers & L. Liukas \\
\hline & A girl who demanded school & K. Ntaiya \\
\hline & A Parkland teacher's homework for us all & D. Wolk-Rogers \\
\hline & A passionate, personal case for education & M. Obama \\
\hline & A police chief with a difference & K. Bedi \\
\hline & A prosecutor's vision for a better justice system & A. Foss \\
\hline & A short intro to the Studio School & G. Mulgan \\
\hline & A summer school kids actually want to attend & K. Abouelnaga \\
\hline & A taboo-free way to talk about periods & A. Gupta \\
\hline & A teacher growing green in the South Bronx & S. Ritz \\
\hline & A university for the coming singularity & R.Kurzweil \\
\hline & Academic research is publicly funded - why isn't it publicly available? & E.Stone \\
\hline & Advice to a young scientist & E.O. Wilson \\
\hline & An ultra-low-cost college degree & S. Reshef \\
\hline & Building blocks that blink, beep and teach & A. Bdeir \\
\hline & Can a robot pass a university entrance exam? & N. Arai \\
\hline & Can I have your brain? The quest for truth on concussions and CTE & B. Nowinski \\
\hline & CERN's supercollider & B. Cox \\
\hline & Dare to educate Afghan girls & S. Basij-Rasikh \\
\hline & Easy DIY projects for kid engineers & F. Qiu \\
\hline & Electrical experiments with plants that count and communicate & G. Gage \\
\hline & Every kid needs a champion & R. Pierson \\
\hline & For these women, reading is a daring act & L. Boushnak \\
\hline & Free or cheap Wii Remote hacks & J. Lee \\
\hline & Gaming to re-engage boys in learning & A. Carr-Chellman \\
\hline & Grit: The power of passion and perseverance & A. Duckworth \\
\hline & Hands-on science with squishy circuits & A. Thomas \\
\hline & Help for kids the education system ignores & V. Rios \\
\hline & "High School Training Ground" & M. London \\
\hline & How Africa can keep rising & N Okonjo-Iweala \\
\hline & How Africa can use its traditional knowledge to make progress & C. Ezeanya-Esiobu \\
\hline & How America's public schools keep kids in poverty & K. Sumner \\
\hline & How Arduino is open-sourcing imagination & M. Banzi \\
\hline & How Argentina's blind soccer team became champions & G. Vilariño \\
\hline & How college loans exploit students for profit & S. Samuel \\
\hline & How I teach kids to love science & C. Harada \\
\hline & How state budgets are breaking US schools & B. Gates \\
\hline & How students of color confront impostor syndrome & D. Simmons \\
\hline & How to design a library that makes kids want to read & M. Bierut \\
\hline & How to fix a broken education system ... without any more money & S. Bansal \\
\hline & How to get better at the things you care about & E. Briceño \\
\hline
\end{tabular}




\begin{tabular}{|c|c|}
\hline How to inspire every child to be a lifelong reader & A. Irby \\
\hline How to learn? From mistakes & D. Laufenberg \\
\hline How to raise successful kids - without over-parenting & J. Lythcott-Haims \\
\hline How we can help hungry kids, one text at a time & S. Kahumbu \\
\hline How we can stop Africa's scientific brain drain & K. Njabo \\
\hline How we'll find life on other planets & A. Shields \\
\hline Kids, take charge & K. Sethi \\
\hline Learn to read Chinese ... with ease! & ShaoLan \\
\hline Lessons from the longest study on human development & H. Pearson \\
\hline Let's teach for mastery - not test scores & Sal Khan \\
\hline Life lessons through tinkering & G. Tulley \\
\hline Looking for a job? Highlight your ability, not your experience & J. Shen \\
\hline Math class needs a makeover & D. Meyer \\
\hline My green school dream & J. Hardy \\
\hline My story, from gangland daughter to star teacher & P. Arredondo \\
\hline Smart failure for a fast-changing world & E. Obeng \\
\hline Sputnik mania & D. Hoffman \\
\hline Teach girls bravery, not perfection & R. Saujani \\
\hline Teach statistics before calculus! & A. Benjamin \\
\hline Teach teachers how to create magic & C. Emdin \\
\hline Teachers need real feedback & B. Gates \\
\hline The 100,000 -student classroom & P. Norvig \\
\hline The best kindergarten you've ever seen & T. Tezuka \\
\hline The boost students need to overcome obstacles & A. Kundu \\
\hline The Chinese zodiac, explained & ShaoLan \\
\hline The economic case for preschool & T. Bartik \\
\hline The global learning crisis - and what to do about it & A. Karboul \\
\hline The joy of lexicography & E. McKean \\
\hline The next generation of African architects and designers & C. Benimana \\
\hline The power of believing that you can improve & C. Dweck \\
\hline The role of faith and belief in modern Africa & N. Nwuneli \\
\hline The search for "aha!" moments & M. Goldman \\
\hline Things I've learned in my life so far & S. Sagmeister \\
\hline This company pays kids to do their math homework & M. Jebara \\
\hline This computer will grow your food in the future & C. Harper \\
\hline This virtual lab will revolutionize science class & M. Bodekaer \\
\hline To learn is to be free & S. Akhtar \\
\hline To raise brave girls, encourage adventure & C. Paul \\
\hline To solve old problems, study new species & A. Alvarado \\
\hline Toy tiles that talk to each other & D. Merrill \\
\hline Turning trash into toys for learning & A. Gupta \\
\hline Want kids to learn well? Feed them well & S. Kass \\
\hline What a bike ride can teach you & S. Schocken \\
\hline What adults can learn from kids & A. Svitak \\
\hline What soccer can teach us about freedom & M. Joseph \\
\hline What we think we know & J. Drori \\
\hline Why lunch ladies are heroes & J. Krosoczka \\
\hline Why massive open online courses (still) matter & A. Agarwal \\
\hline Why must artists be poor? & H. Eldebek \\
\hline
\end{tabular}




\begin{tabular}{ll}
\hline Why open a school? To close a prison & N. Lopez \\
\hline Why school should start later for teens & W. Troxel \\
\hline Why some of us don't have one true calling & E. Wapnick \\
\hline Why the live arts matter & B. Cameron \\
\hline Why you should love statistics & A. Smith \\
\hline
\end{tabular}

\section{Appendix B. Fixed expressions denoting different levels of commitment}

Fixed expressions denoting certainty

I bet (that)...

I come to the conclusion that...

I have great hope that...

I know (that)...

I strongly believe (that)...

I'm (strongly/ firmly) convinced (that)...

I'm sure (that)...

It makes no odds.

It's clear/ obvious/ true (that)...

It's impossible for us (not) to...

It's most/ much more likely to...

It's no wonder (that)...

It's very likely that...

Needless to say, ...

No wonder (that)...

Of course/ Of course not.

That must be...

That's for sure.

There's a high probability (that)...

There's no question (that)...
Fixed expressions denoting certainty

I bet (that)...

I come to the conclusion that...

I have great hope that...

I know (that)...

I strongly believe (that)...

I'm (strongly/ firmly) convinced (that)...

I'm sure (that)...

It makes no odds.

It's clear/ obvious/ true (that)...

It's impossible for us (not) to...

It's most/ much more likely to...

It's no wonder (that)...

It's very likely that...

Needless to say, ...

No wonder (that)...

Of course/ Of course not.

That must be...

That's for sure.

There's a high probability (that)...

There's no question (that)...

Fixed expressions denoting possibility

I wonder...

It can possibly be...

It is doubtful that...

It is less likely to...

It is possible to/ that...

It might be... 